\title{
高蔵寺ニュータウンにおける住宅ストック及び施設分布からみた 再生手法に関する考察 \\ CONSIDERATION OF REGENERATIVE METHOD VIEWED FROM RELATIONSHIP BETWEEN HOUSING STOCK AND DISTRIBUTION OF FACILITIES IN KOZOJI-NEWTOWN
}

\author{
納 村 信 之*1, 伊藤義 浩*2, 岩佐 育恵*3, 太幡英 亮*4 \\ 恒川和久 ${ }^{* 5}$, 川野紀 江*6, 村上 心*7, 谷口 元*8 \\ Nobuyuki NOMURA, Yoshihiro ITOH, Ikue IWASA, \\ Eisuke TABATA, Kazuhisa TSUNEKAWA, Norie KAWANO, \\ Shin MURAKAMI and Gen TANIGUCHI
}

\begin{abstract}
This study is aimed to consider the regenerative method viewed from the relationship between the housing stock and the distribution of facilities in and around Kozoji Newtown. As the results we found that more people tend to live around the Newtown because more numbers of commercial facilities has been located around rather than within the Newtown. It causes that the Newtown has remained an only residential town because facility location is legally or as some rules restricted in the most of the areas except the center area. Therefore we consider that it is important to give each area some added value and attractiveness by promoting commercial use in UR rental housing blocks or detached housing areas in order to increase the numbers of new residents in the Newtown.
\end{abstract}

Keywords : New town, Housing stock, Empty housing lots and vacant houses, Distribution of facilities ニュータウン, 住宅ストック, 空き地・空き家・空室，施設分布

\section{1. 研究の概要}

\section{1-1. 研究の背景}

高度経済成長期に都市部への人口流入が起こり、その為の受け 皿として多くのニュータウン（以下 NT）が建設された。しかし、 低成長・人口減少・少子高齢化等の現代社会では、都市を縮小寸 る方向へと進まなければならなくなった。なかでも大規模 NT には、 当時高度に整備されたストックが存在し、これらは都市の縮小時 代に対して重要な意味合いを持っている。その一方、近代的な計 画により建設された NT が現代の社会に適応できず、様々な問題が 露呈している。一つに、NT の初期入居の段階で子育て期の核家族 の入居が大半を占めており、その核家族の世帯分離が急速に進展 した事が挙げられる。そのため、世帯数の変化は小さいものの、 世帯人員が大きく減少、また急速な高齢化の進行に繋がっている。 さらに、大量供給を行ったため、公共賃貸住宅及び分譲集合住宅 の更新時期を一斉に迎えていることや、当時の画一的な住宅構成
が現在の多様なライフスタイルに対応できていないことも問題と して挙げられる。二つ目は、NT 内にある近隣センター等の商業施 設の衰退も問題である。大型マーケットやモータリゼーションに よる生活圈の拡大に伴う購買行動の変化に対応しきれず、店舗経 営の前時代性、アメニティの欠如などから衰退するとともに、ス プロールの抑制効果を期待された NT 周辺での市街地拡大も問題と なっている。

\section{1-2. 既往研究の整理と本研究の位置づけ}

本研究の目的と方法の位置付けを行うために、NTを含む住宅地 に関する研究がどのような課題に取り組んできたかを示す。建築 計画における NT に関する研究は、以下の住宅ストックと施設配置 に関する 2 つ研究に大別できる。

(1)住宅ストックに関する研究 : 住み替え、空き地・空き家数の分 布調查

原田 ${ }^{1)}$ によって、高蔵寺 NT 内での住み替えが顕著に行われてい
*1 名古屋商科大学院マネッジメント研究科 教授・博士 (工学)

*2 INA 新建築研究所

*3 名古屋大学大学院環境学研究科 博士前期課程

$* 4$ 名古屋大学大学院工学研究科 助教・博士 (工学

*5 名古屋大学大学院工学研究科 准教授・博士 (工学)

*6 椙山女学園大学生活科学部 助教

$* 7$ 椙山女学園大学生活科学部 教授・博士 (工学)

$* 8$ 名古屋大学施設計画推進室 特任教授・博士 (工学)
Prof., Division of Business Administration, The NUCB Graduate School, Dr. Eng. Institute of New Architecture Inc. Graduate Student, Environmental Studies, Nagoya Univ. Assistant Prof., Graduate School of Engineering, Nagoya Univ., Dr. Eng. Assoc. Prof., Graduate School of Engineering, Nagoya Univ., Dr. Eng. Assistant Prof., Sci. of Life Studies, Sugiyama Jogakuen Univ.

Prof., Sci. of Life Studies, Sugiyama Jogakuen Univ., Dr. Eng. Prof., Campus Planning and Management Office, Nagoya Univ., Dr. Eng. 
る実態が示されている。片山ら ${ }^{2)}$ は、人口と世帯数の増加率を分析 項目として取り上げ、モデル図を提示し、岐阜県内の団地に適応す ることで、衰退の様子を捉えている。小西ら ${ }^{3)}$ は、千里 NT を対象と し、空き地・空き家調査を行い、その分布における考察を行っている。 菊池 ${ }^{4)}$ は、世帯移動に伴って生じる空き家数の変化を算出し、空 き家数をモデル的に算出・検討する試みを行っている。

(2)施設配置に関する研究 : 施設数と人口の増減、開発手法や協定と の関係

森田 ${ }^{5)}$ は、高蔵寺 NT の施設増減を調查し、施設原単位の経年変動 の 4 つの型に分け、人口に比例して施設が設けられる「横ばい型」 以外は人口の変動を深く考慮する必要があるとしている。柏原ら ${ }^{6)}$ によって、各種 NT における施設発生の実態を調査し、それと人口、 各種開発手法、建築協定などとの関係を明らかにする試みがなされ ている。石橋ら ${ }^{7)}$ は、多摩田園都市において生活関連施設の立地経 緯を調査し、同じ区画整理手法による開発地区でも、施設原単位と その経年変化は多様であることを示している。

上記のように、特定の NT や住宅地に対して住み替えや住宅ストッ クの実態把握を行うものや施設の将来展望を求める研究は数多くな されている。しかし、住宅ストックと施設配置との関係を扱った研 究や、大規模 NT とその周辺部を含んだ総合的視点にたった研究は少 ない。総合的視点にたった研究が重要である理由の一つには、住宅 ストックの価値が周辺の施設立地などの環境に大きく影響されると 考えられる。更に、NT 周辺への住宅地のスプロール化が問題であり ながらも居住地として選ばれている状況が上げられる。そこで、本 研究は、NT とその周辺における住宅ストックと施設分布との関係を 分析することで、NT 再生の手法を考察することを目的とする。

\section{1-3. 研究の方法}

調查対象の NT は、名古屋市北東に隣接する春日井市内、名古屋中 心部から $20 \mathrm{~km}$ 、岐阜との県境に間近な丘陵地に位置する高蔵寺 NT で ある。戦後日本の高度経済成長に伴う都市化と都市への急激な人口 流入により、名古屋圏においても 50 年代〜 60 年代の人口が $54 \%$ 増 であった。「高蔵寺 NT」計画は、それを補う受け皿として 1960 年、 日本住宅公団によりスタートした。総面積 702ha、計画人口 81,000 人、計画戸数 20,600 戸であり、土地区画整理事業として公的大規模 開発が行われた。交通としては、ニュータウンの南端に JR 中央本線 の高蔵寺駅があり、北側には国道 19 号線が通過している。マスター プランにおいて特筆すべきは、中央センター（以下センター）に集 約された都市機能と、谷筋を走る幹線道路によって構成される「口 ンセンター・システム」である。ただし、実施計画では、ワンセン ター・システムが修正されてセンターと住区サービス用のサブ・セ ンターの 2 段階構成がとられた。

調査方法は以下の 4 つの NT とその周辺における住宅ストック及び 施設分布の調査・分析からなる。

a) マクロな視点における高蔵寺 NT の位置づけ

2 章では名古屋大都市圏注 1$)$ を対象として高蔵寺 NT の住宅と住民 特性を把握する。

b) 住宅ストックと人口・世帯からみる各町丁目の分類

3 章では高蔵寺 NT とその周辺を対象とし、2005〜 2011 年の世帯 増加率と 2005 年の空き家・空き地調査を基に、NT 内の各町丁目を分 類する。 c）施設分布の把握

4 章では住宅地図を用いて施設の位置をプロットし、NT 内及び周 辺の施設分布特性をみる。

d）住民の意向・施設ニーズの把握

5 章ではNT 居住者を対象にアンケート調査を行い、居住者の今後 の意向と施設ニーズを把握する。また、3 章で行った分類ごとにおけ る住民の意識、施設ニーズと 4 章で把握した実際の施設分布の比較 をそれぞれ行い、その関係をみる。

以上を通してNT の特性・問題点の整理、さらには再生手法に関す る考察を行う。

\section{2. 名古屋大都市圏における高蔵寺地区の位置づけ}

\section{2-1. メッシュデータでみる世帯特性}

平成 17 年国勢調査地域メッシュ統計注 2$)$ を基に、名古屋都市圈を 対象にメッシュ統計を 4 次メッシュ（約 $500 \mathrm{~m}$ 四方）に割り付け、地 域の特性を視覚的に把握するとともに、統計資料から高蔵寺 NT の特 徵を以下の 3 項目で捉えた。

a) 所有の関係別住宅状況比率 : 持ち家世帯は名古屋から遠ざかる程

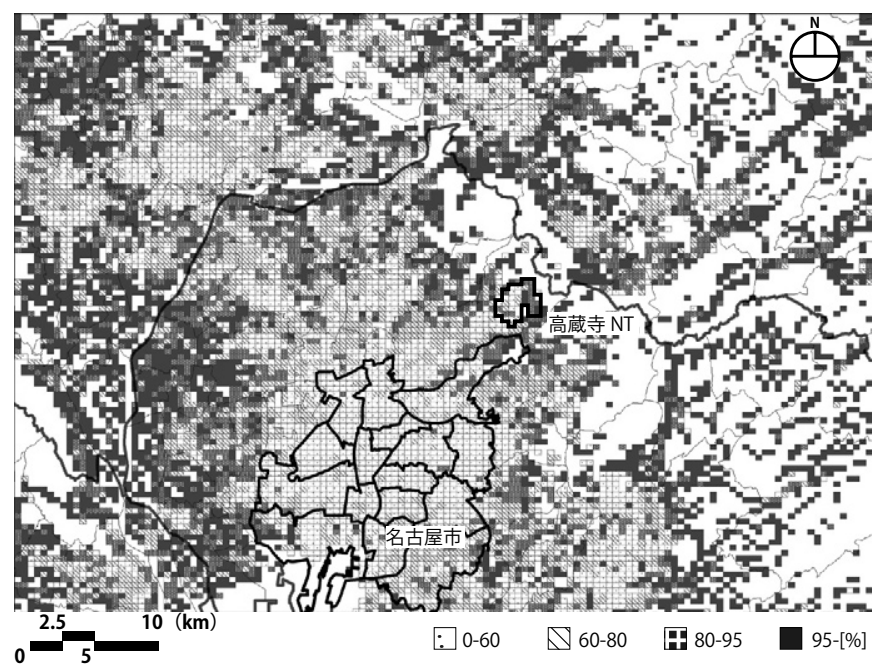

図 1 名古屋大都市圈における持ち家世帯比率 (2009 年)

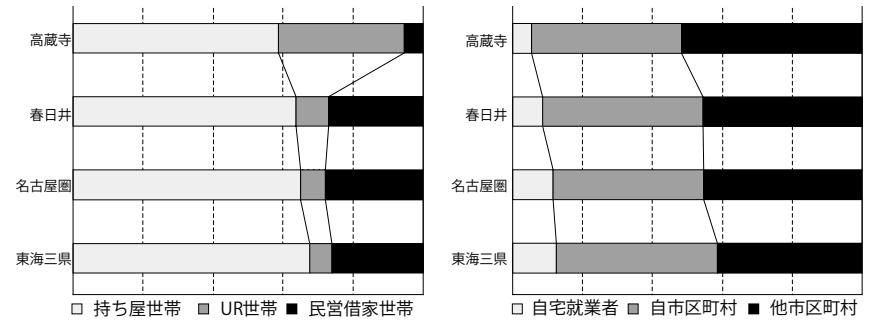

図 2 所有の関係別住宅状況割合 (2009 年) 図 4 就業地割合 (2009 年)

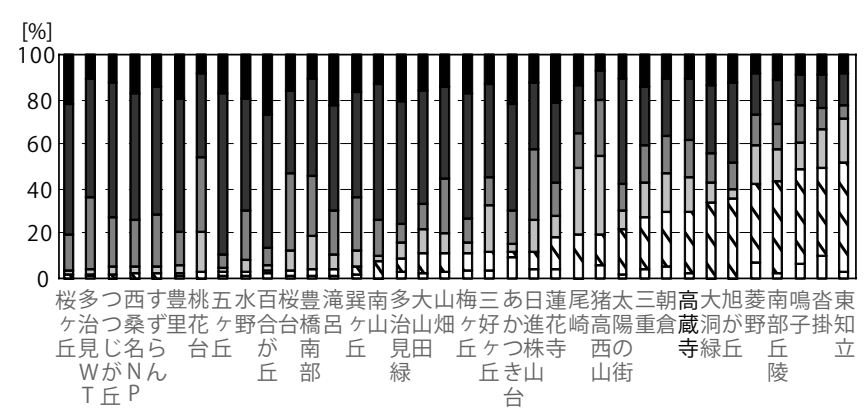

$\square 0 \sim 29 \mathrm{~m}^{2} \nabla 30 \sim 49 \mathrm{~m}^{2} \square 50 \sim 69 \mathrm{~m}^{2} \square 70 \sim 99 \mathrm{~m}^{2} \square 100 \sim 149 \mathrm{~m}^{2} \square 150 \mathrm{~m}^{2} \sim$ 図 3 住宅延べ面積割合 (東海三県 NT，2009 年) 
に比率が高い $(\text { 図 1 })^{8)}$ 。高蔵寺 NT はその境目に位置し、UR 都市機 構（以下 UR）借家世帯比率も高い。東海三県、名古屋大都市圈、春 日井市における所有の関係別住宅状況に大きな違いはみられず、持 ち家世帯比率が 6 割以上、民営借家世帯比率が約 3 割であるが、高 蔵寺 NT においては持ち家世帯比率が 6 割を下回り、UR 賃貸世帯が約 4 割である。すなわち高蔵寺 NT が、持ち家と UR 賃貸の混在する状況 であることを示している(図 2) ${ }^{8)}$ 。

b) 住宅延べ面積比率 : 東海三県における NT を含むメッシュに対して 住宅延べ面積割合を示す (図 3)。ここでNT を計画開発住宅市街地と 定義する。計画開発住宅市街地とは、大都市圈に流入する人口を吸 収するために計画的に開発された近隣住区に相当する住宅戸数 2000 戸以上の住宅市街地である 注 3$)$ 。東海三県の NT と比較すると高蔵寺 NT には、0〜 $29 \mathrm{~m}^{2} 、 150 \mathrm{~m}^{2}$ 以上の住宅は少なく、30〜 $149 \mathrm{~m}^{2}$ の住宅 が比較的均等に存在している。

c) 就業地比率 : 自宅就業者比率は、自市・他市区町村の就業者と比 較して低い值を示しているが、高蔵寺 NT ではさらに低い值を示して いる。春日井市内の人々は市内での従業者と市外での従業者が同数 程度である。しかし、高蔵寺 NT では市外での従業者数が比較的高い 值を示しており、現在でもベッドタウンとしての特性を持つことが 示された（図 4) ${ }^{8)}$ 。

\section{3. 住宅ストックと人ロ・世帯からみる各町丁目の特性 \\ 3-1. 人口・世帯数の推移}

$2000 \sim 2005$ 年、2005 2011 年の高蔵寺 N T とその周辺で、町丁 目ごとの世帯数と人口の変化を示す注 4) (図 5)。本章において NT 周 辺をNT に隣接する町丁目が全て包含される範囲として、センター地 区を中心とした $6 \mathrm{~km}$ 四方をとした。なお、 $6 \mathrm{~km}$ の区分線上に町丁目が ある場合、面積の半分以上を含む町丁目を含入した注 5）。NT 内では 世帯数・人口ともに増加している町丁目が 6 割であったのが、2005 年以降では人口減に転じている町丁目が 6 割である。NT 周辺では、 2000 ～ 2005 年において様々な值を示していたが、2005 年以降は世 帯数・人口ともに増加に転じている町丁目が 6 割を超えており、NT 内とは対照的な傾向を示している。

\section{3-2. 世帯増加率と空き地・空き家による各町丁目の分類}

2010 年 3 月における高蔵寺ニュータウンの住宅戸数は、21, 838 戸。 その $42 \%$ を占める戸建住宅と $36 \%$ を占める UR 貸貸集合住宅を本論 の対象住戸として選定して調査分析していく注 6)。まず、2005 年に おける空き地・空き家調査データ注 7) を基にNT における町丁目ごと の空き地・空き家の算出を行った。ここで、空き地・空き家率を、 2005 年世帯数に対する空き地・空き家・空室数の百分率と定義する。 また、UR 貸貸集合住宅で構成される町丁目（以下 UR 賃貸地区）は UR 貸貸集合住宅の世帯数に対する空室数、それ以外の戸建住宅で構 成される町丁目（以下戸建地区）は戸建住宅の世帯数に対する空き 地・空き家数として算出する。そして、2005 年における空き地・空 き家率と 2005 ～ 2011 年での世帯増加率の 2 軸から NT 内の町丁目を 4 つに分類した注 ${ }^{8)}$ (図 6、7)。軸の交点は同年における春日井市の 世帯増加率、突出した 3 町丁目を除いた空き地・空き家の平均值で ある。合計 54 町丁目中 42 町丁目が戸建地区、12 町丁目が UR 賃貸地 区に該当した。

\section{3-3. 空き地・空き家・空室の推移}

NT の大半を占める分類 $\mathrm{a} \cdot$ 分類 $\mathrm{b} \cdot$ 分類 $\mathrm{c}$ のうち、典型的な例とし て注 9) 岩成台 7 丁目、高森台 6 丁目、高森台 1 丁目をそれぞれ挙げ、 空き地・空き家を目視により把握した注 10$)$ 。また、2005 年時点での 空き地・空き家からの変遷を追った（表 1 , 図 8,9) 注 11)。世帯増

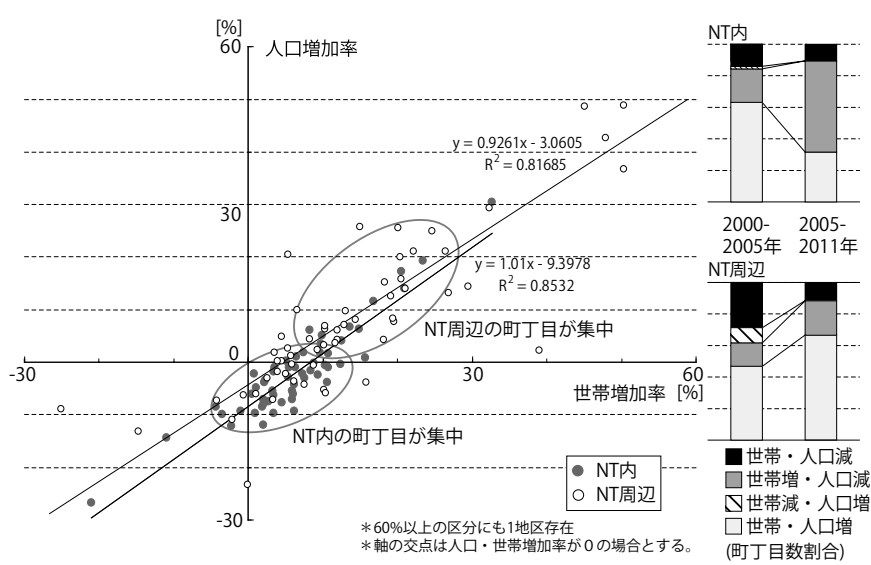

図 5 世帯数・人口推移 $(2005 \sim 2011$ 年 $)$

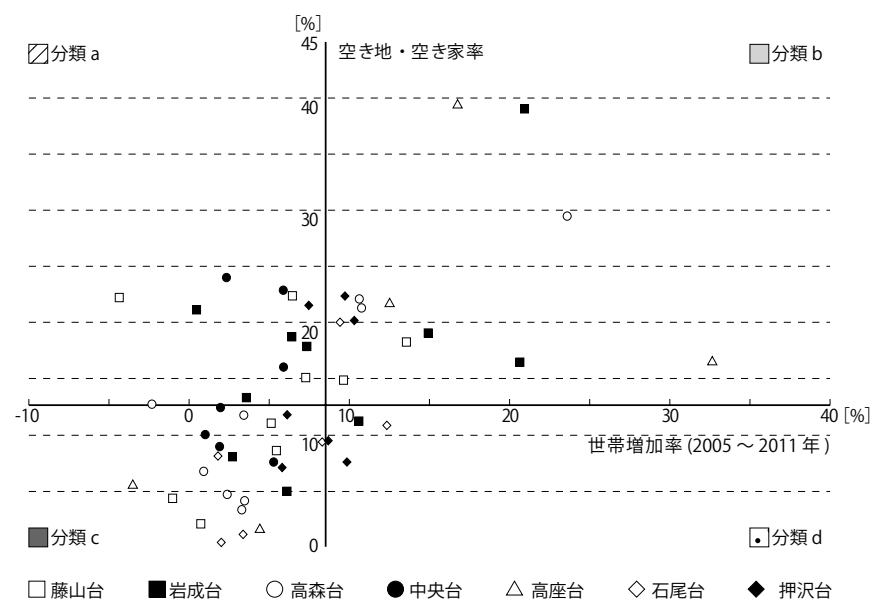

図 6 世帯増加率と空き地・空き家・空室率 (町丁目別)

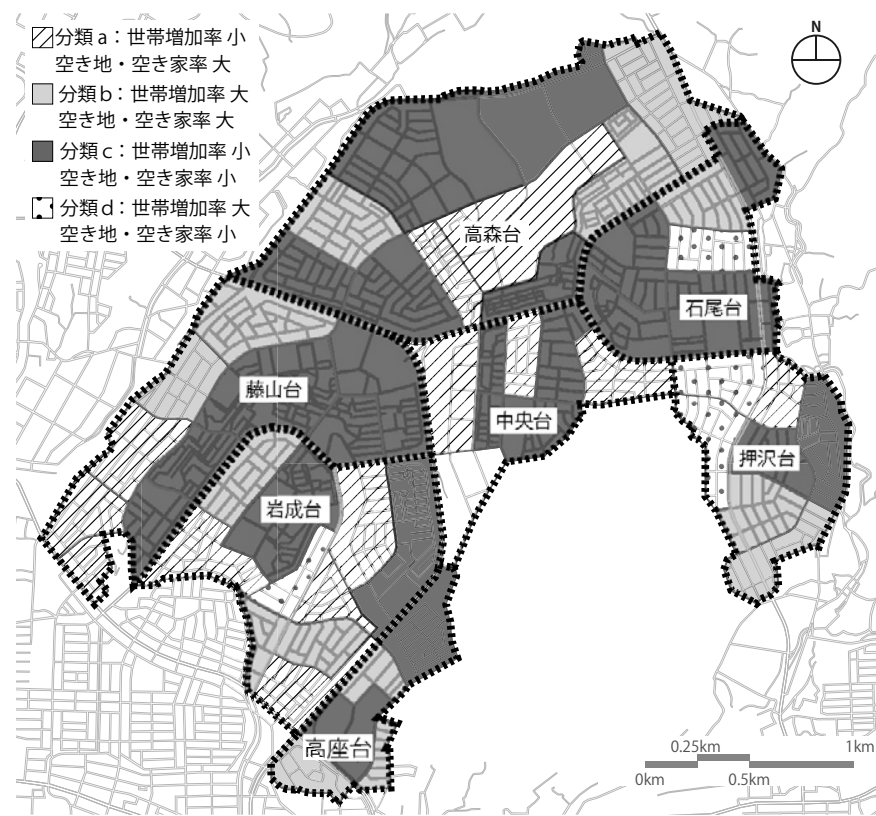

図 7 NT 内各町丁目の分類 
加率が低く、2005 年時点での空き地・空き家率が高い分類 a では、 空き家発生数と新規の住宅発生数が同数程度であり、住宅地として 同程度の密度を保っている。世帯増加率も2005 年時点での空き地・ 空き家率も高い分類 $\mathrm{b}$ では、空き地に多くの新規住宅開発がみられ、 それにより世帯が増加している。世帯増加率が低く、2005 年時点で の空き地・空き家率も低い分類 $\mathrm{c}$ では、空き家が増加しており、今 後も空き家が発生し、世帯は減少に転じる傾向があるといえる。

また、分類 $\mathrm{c}$ のUR 賃貸地区についても、センターから最も遠い地 区と最も近い地区を抽出して 2005 年時点からの空室率の推移を 2005 年の調査同様目視により調査した ${ }^{\text {注 }}{ }^{10)}$ 。結果、センターに近い中央 台 3 丁目の空室率はあまり変化が無かったが、センターから遠い藤 山台 4 丁目の空室率は約 7 倍と激増していた。（表 2, 図 9)。

\section{3-4. 各地区特性の考察}

上記の調查から以下に住宅ストックからみた各地区の現状特性を述 ベる。

\section{a) 戸建地区}

・世帯増加率が低く、空き地・空き家率が高い分類 $\mathrm{a}$ の戸建地区では、 空地と新規住宅発生数が同程度であった。しかし、開発時期の早い 地区が多く含まれることから今後のさらなる高齢化を考えると衰退 が進行していく可能性があるといえる。

・世帯増加率が高いにも関わらず空き地・空き家率が高い分類 $\mathrm{b}$ は、 表 1 からも空きに新規世帯が入ってきていると考えられる。未だ多 くの空地が存在することから、人口流入の余地を残しており、今後 も空き地や空き家が活用されていけば世帯循環は継続されると考え られる。これらの地区には高座台・高森台などの NT の端、センター から遠い町丁目に集中している。

表 1 戸建地区の空き地・空き家の推移 (2005 年 11 月～2012 年 1 月)

\begin{tabular}{|c|c|c|c|c|c|c|c|c|c|c|c|}
\hline \multirow{2}{*}{ 分類 } & \multirow{2}{*}{ 町丁目 } & \multicolumn{2}{|c|}{ 空き地 } & \multirow{2}{*}{$\begin{array}{l}\text { 空き地 } \\
\text { 增減数 }\end{array}$} & \multirow{2}{*}{$\begin{array}{l}\text { 空き地 } \\
\text { 新築 }\end{array}$} & \multirow{2}{*}{$\begin{array}{l}\text { 新規 } \\
\text { 空き地 }\end{array}$} & \multicolumn{2}{|c|}{ 空き家 } & \multirow{2}{*}{$\begin{array}{l}\text { 空き家減数 } \\
\end{array}$} & \multirow{2}{*}{$\begin{array}{l}\text { 空き家 } \\
\text { 新築 }\end{array}$} & \multirow{2}{*}{$\begin{array}{l}\text { 新規 } \\
\text { 空き家 }\end{array}$} \\
\hline & & 2005年 & 2012年 & & & & 2005年 & 2012年 & & & \\
\hline a & 岩成台7丁目 & 22 & 17 & -5 & 8 & 0 & 8 & 14 & 6 & 0 & 6 \\
\hline $\mathrm{b}$ & 高森台6丁目 & 73 & 46 & -27 & 32 & 1 & 7 & 5 & -2 & 2 & \\
\hline $\mathrm{c}$ & 高森台1丁目 & 15 & 11 & -4 & 5 & 1 & 1 & 9 & 8 & 1 & \\
\hline
\end{tabular}

表 2 UR 賃貸地区の空室の推移 (2005 年 11 月～ 2013 年 1 月 )

\begin{tabular}{|c|c|r|r|r|r|r|r|}
\hline \multirow{2}{*}{ 分類 } & \multirow{2}{*}{ 町丁目 } & \multicolumn{3}{|c|}{2005} & \multicolumn{3}{|c|}{2013} \\
\cline { 3 - 8 } & & 世帯数 & \multicolumn{1}{c|}{ 空室 } & 空室率 & 世帯数 & 空室 & 空室率 \\
\hline $\mathrm{c}$ & 中央台3丁目 & 260 & 26 & 10.00 & 265 & 21 & 7.92 \\
\hline $\mathrm{c}$ & 藤山台4丁目 & 1055 & 45 & 4.27 & 851 & 249 & 29.26 \\
\hline
\end{tabular}
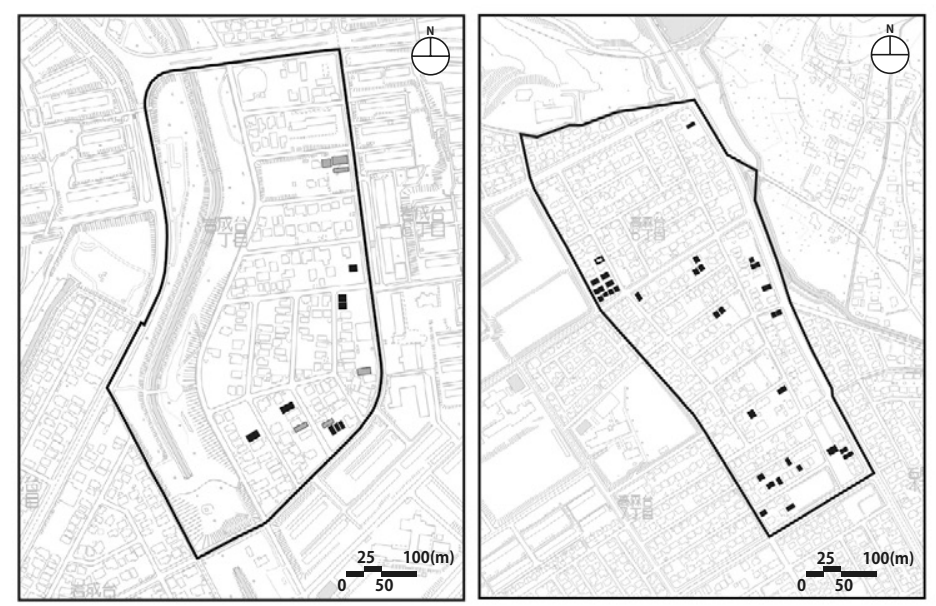

・世帯増加率、空き地・空き家率共に低い值を示寸分類 $\mathrm{c}$ は、人口 流入の余地の少ない成熟した状態にあると言える。一方で表 1 より、 空き家の増加する傾向がみられることから、空き家を利用した世帯 の循環が求められる。センター付近の地区においてもこうした特性 を持つ地区が多い。

・世帯増加率が高く、空き地・空き家率が低い值を示す分類 $\mathrm{d}$ は住 宅地として飽和状態に近いと考えられる。この分類に含まれるもの は少なく、かつ含まれた町丁目も世帯増加率が $10 \%$ 、空き地・空き家 率が $10 \%$ と特別この特性が強いわけではない。石尾台・押沢台とい ったセンターから離れた比較的開発時期の遅い地区が多く含まれる。 b) UR 賃貸地区

12 の UR 賃貸地区の中で 9 地区が分類 c、3 地区が分類 a に該当し、 全ての地区が世帯増加率が低い状況であった。分類 c においてセン ターに近い地区は空室率の推移にあまり変化が見られない。一方、 遠い地区において空室率の増加が顕著であり、今後何らかの対策を 講じなければ衰退が進行して行くことが予想される。

\section{NT と周辺における施設分布}

\section{4-1. 調査対象と方法}

3 章同様 NT 内の中央センターを中心とした $6 \mathrm{~km}$ 四方に含まれる全

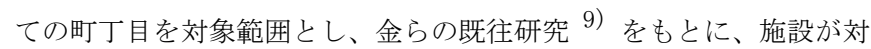
象エリアに存在しない時計店、メガネ屋、カメラ屋と下請けの店舗 が多いクリーニング店を除き、コンビニエンスストアを加えた 15 業 種を分析する。そして、1981・1991・2001・2010 年のゼンリンの住 宅地図注 12$) 、 2011$ 年の Google map 注 ${ }^{13)}$ を用いて商業施設の分布と 変遷を把握し、用途地域注 14）と幹線道路 注 15）との関係を明らか にしていく。

\section{4-2. 各業種の建築制限地域と施設数}

飲食店を例に挙げ、対象範囲の用途地域による建築制限地域を色 分け寸る (図 10)。NT 内の立地が可能な地域は、センター地区（近 隣商業・商業地域）と計画が予定されていたペデストリアンデッキ 周辺（主に、第一種中高層・住居専用地域）に配置され、その周縁 に立地が制限される地域（主に、第一種低層住居専用地域）が配置 されていることが分かる注 16)。また、前章で行った図 7 の町丁目の 分類と図 10 を比較すると、分類 $\mathrm{c}$ と施設の立地が可能な地域とが多 く重なっており、分類 $\mathrm{b}$ と施設の立地が制限される地域とが多く重
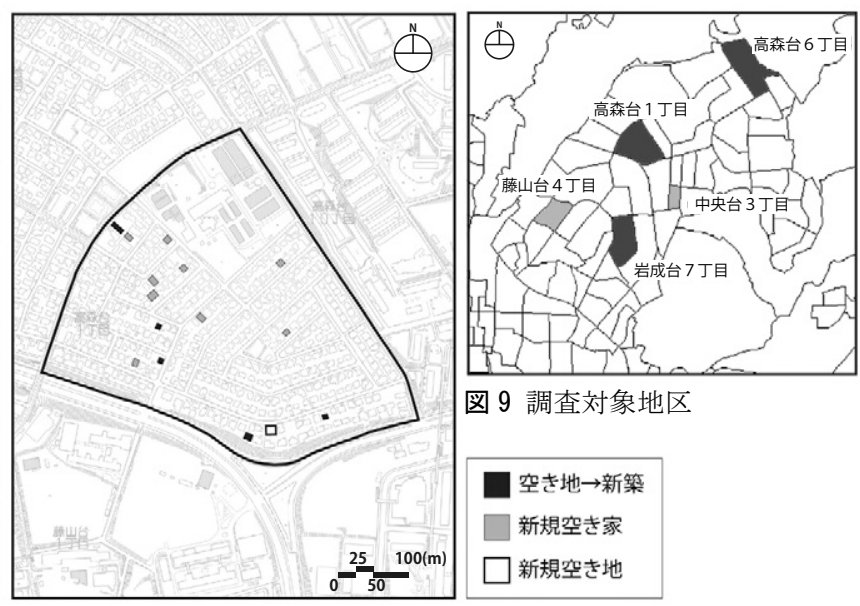

図 9 調查対象地区

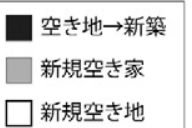

図 82005 ～ 2012 年の空き地・空き家推移 (左図から岩成台 7 丁目、高森台 6 丁目、高森台 1 丁目) 
なる。つまり、分類 c の戸建地区の空き家やセンターから遠い分類 c のUR 賃貸地区の空室が増大しており、分類 $\mathrm{b}$ の戸建地区では世帯の 流入している状況から、今後施設の立地しにくい地区で世帯が流入 し、施設立地しやすい地区では世帯が減少する傾向にあるといえる。

次に、2011 年時点の選定した 15 業種の建築制限地域に対寸る施設 数を示す（図 11）。NT 内より圧倒的に多い NT 周辺の飲食店や美容・ 理容院は立地が可能な地域に多く立地している。一方、施設数の多 いNT 内の文化教室では立地が制限される地域に多く立地している。 また、NT 外では様々な業種が市街化調整区域にも立地している。

\section{4-3. 業種ごとにみる施設分布}

前項で選定した 15 業種の中で飲食店、文化教室そして食料品店を 抽出し、2011 年の Google map を用いて業種ごとに施設をプロットし た（図 12）。飲食店はNT 内ではセンターやサブセンターに集積して いるが、住宅地内部での立地はほとんどみられない。NT 周辺におい ては近隣商業地域の幹線道路沿いに集中して立地している。一方、 文化教室についてはNT 内・周辺ともに住宅地内部での立地が多い傾 向にあり、NT 内では用途地域の制限によって住宅併設店舗としての 形態をとっているものが多いと考えられる。食料品店は、NT 内では、 日常的に利用頻度の高い施設にもかかわらずサブセンターや住宅地 内部にまばらにしか分布していないが、NT 周辺では高蔵寺駅南側や 住宅地内にも多く分散して分布している。総じて、NT 内では施設に よって立地にばらつきがあり、周辺では、住宅地内にも多数施設の 立地がみられ、用途の混在した市街地を形成していることがわかる。

\section{4-4. 各業種の新設・存続・消滅施設数}

これまで、各種施設の立地の傾向を NT内外で比較してみてきたが、 次に、今後の展望を予測するために、前項の 3 業種の過去 30 年にお ける NT 内外における施設数の増減を調べた（図 13、14）。飲食店に おいて、NT 内では飲食店の施設数が減少し始めているのに対して、 NT 外では増加している。食料品店数は、NT 周辺では施設の減少が落 ち着いきているのに対して、NT 内では消滅施設数が増加しているこ とからこれからも減少することが予想される。このことから、NT 周 辺において飲食や食料品店といった利便性が高く街の魅力を向上さ せるような施設が増加していることが、NT 内と対照的に人口増に転 じる傾向にある一因であると考えられる。一方、文化教室において、 NT 内・周辺で未だに新設施設数が増加している。同時に消滅施設数 も増加傾向にあるが、それを上回る数が発生しているので、存続施 設数も増加してきている。これは、 NT 内・周辺共に住宅地内での活

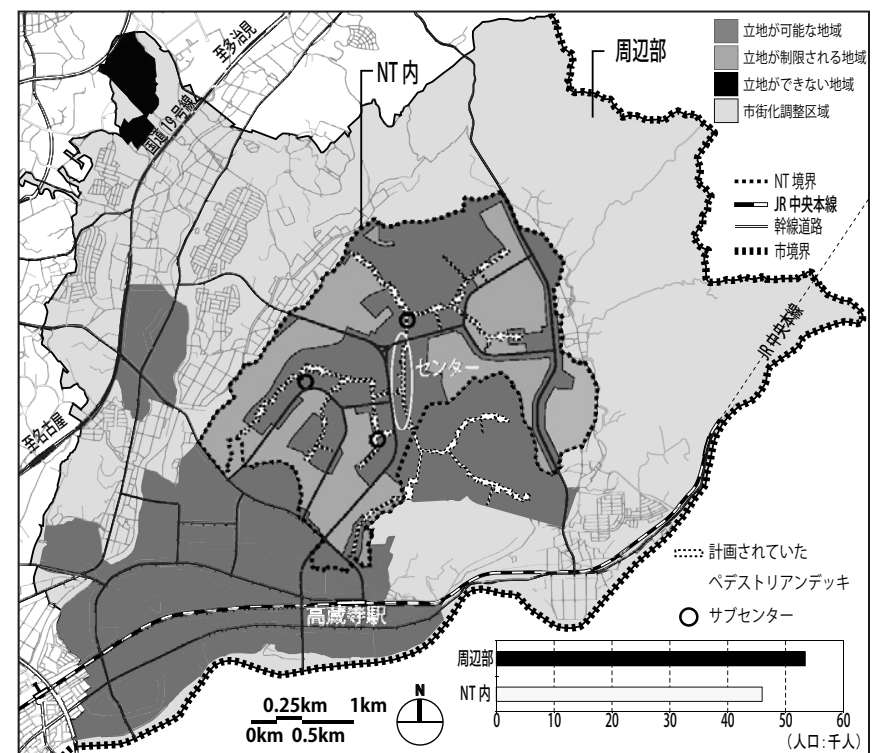

図 10 対象範囲における飲食店の建築制限地域の分布

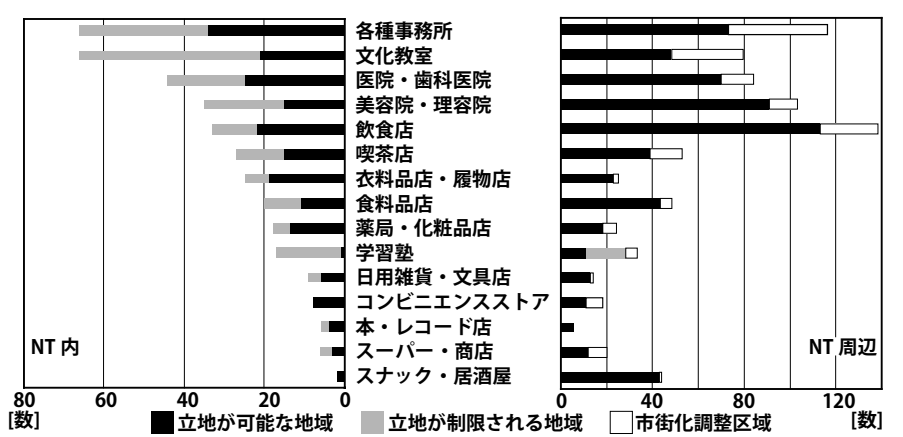

図 11 各業種の用途地域に対する施設数

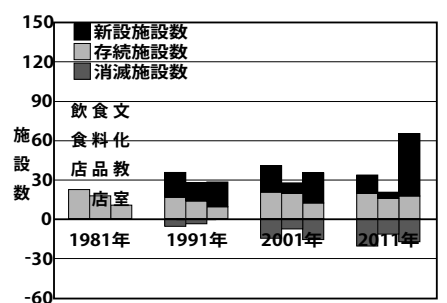

図 13 NT 内の新設・存続・消滅施 設数

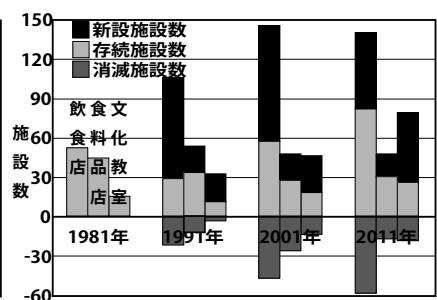

図 14 NT 周辺の新設・存続・ 消滅施設数

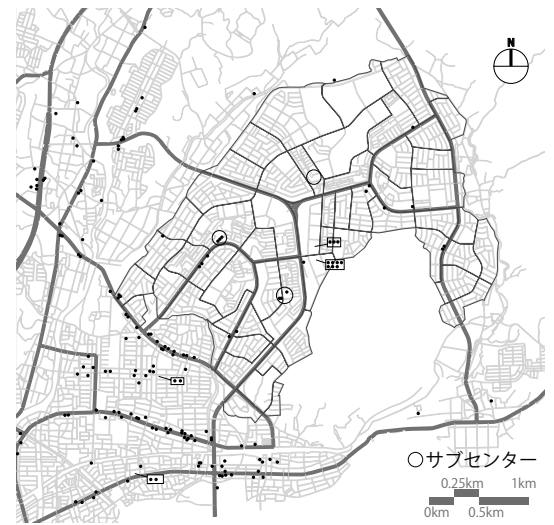

図 12 施設分布 飲食店

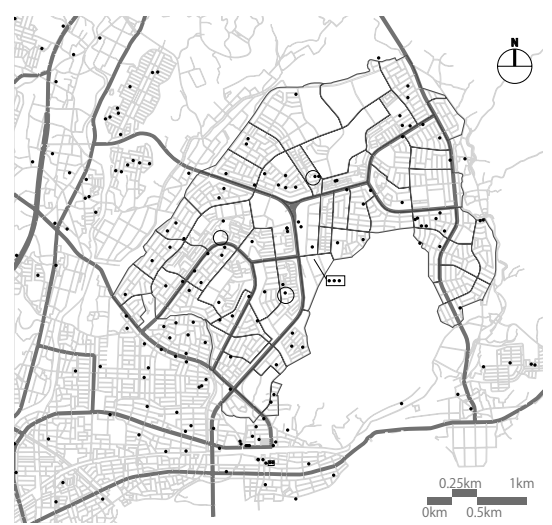

文化教室

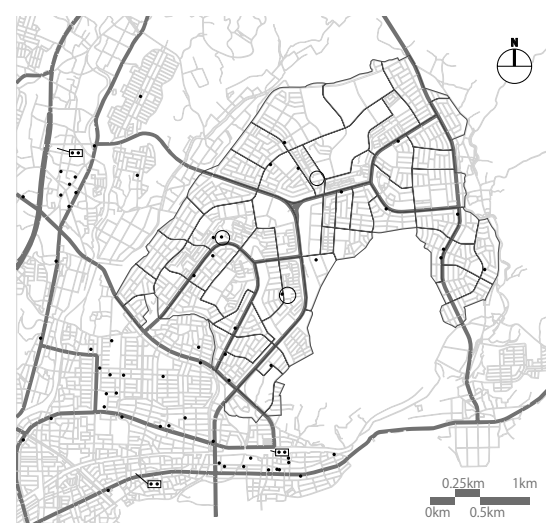

食料品店 
動が活発化してきており、これからも増加していくだろうと予想で きる。

\section{5. 住民の意識と評価}

\section{5-1. アンケート概要}

NT 内の居住者を対象にアンケート調查を行い、住民の住居に対寸 る意識や施設ニーズを把握した注 17 )。(図 15, 表 3$)$ 。さらに、3 章 で行った分類毎の住民の意識や施設ニーズと 4 章で行った施設分布 との関連性をみた。複数回答を認めているため、集計では 1 人当た りの回答数を単位とした。

\section{5-2. 住民属性の特徵}

年代別における住居選定の理由を示寸（図 16）。40 代以降の世代 において静かな居住地を選定理由に挙げる回答者の比率が高い。一 方、20 代や 30 代の若い世代において家賃、日常の買い物等の利便性 を選定理由に挙げている回答者が多く、若い世代においては住居を 選ぶ際の大きな要素であるといえる。

次に、NT内の各町別に住民が自宅周辺に欲しい施設を示す（図 17)。結果、センターに位置する中央台を除いた全ての町で物販や飲 食店などの日常的に利用する施設の需要が高かった。特に、藤山台 や押沢台といったセンターから遠くなるほど高い比率を占めている ことが分かる。

\section{5-3. 地区の分類と住民特性}

分類 $\mathrm{b}$ ・分類 $\mathrm{c}$ に対し、居住年数と住居選定の理由をみた（図 18）。居住年数に関しては、分類 $\mathrm{b}$ ・分類 $\mathrm{c}$ の戸建地区を比較すると、 分類 $\mathrm{b}$ では、開発時期以降にも世帯の流入がみられるが、分類 $\mathrm{c}$ で は $30 \sim 39$ 年の世帯の割合が多く、開発当初からの居住者が多く占 めていると考えられる。一方、分類 c $の$ UR 賃貸地区において 4 年以 内の居住者が 3 割を超えており、世帯の短期の流出入がみられる。 住居選定の理由に関しては、分類 $\mathrm{b}$ ・分類 $\mathrm{c}$ の戸建地区では自然環境 や静かな住宅地を、また、分類 c の UR 賃貸地区では、家貨が適当以 外に公共交通機関と買い物等の利便性を理由に挙げる回答者が多い。 以上のことから、UR 貸貸住宅一と住む人々は買い物や交通機関の利 便性を重視し、センター周辺の地区に住み、戸建住宅へと住む人々 は自然環境・静かな住宅地を求め、センターから離れた地区に住む という大きくこの 2 つのタイプの住民が多いと考えられる。

\section{5-4. 施設ニーズと分布の関係}

自宅周辺に欲しいと思う施設と実際の分布との関係をみた。対象 町丁目の重心位置から半径 $500 \mathrm{~m}$ をその町丁目の徒歩圈と定義し 注 18)、その範囲内の施設数とその町丁目における施設ニーズの相関 をみた。比較的大きな相関はみられず、学習教室や集会所において はニーズに対し施設数の多い町丁目が大半である。最もニーズにば らつきのある食料品店について分類 $\mathrm{b}$ と分類 $\mathrm{c}$ を比較すると、施設 数は同数程度であるのに対し、分類 $\mathrm{b}$ においては施設ニーズが約 0.7

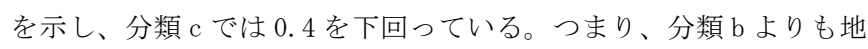
区 $\mathrm{c}$ の方が施設に対する満足度が高いことを示している(図 19)。こ れは、分類 $\mathrm{b}$ の両町丁目がセンターから遠く位置するのに対し、分 類 $\mathrm{c}$ の高森台 1 丁目はセンターに近く、石尾台 $6 丁$ 丁目にはセンター 以外に唯一スーパーマーケットが存在していることが原因と考えれ る。

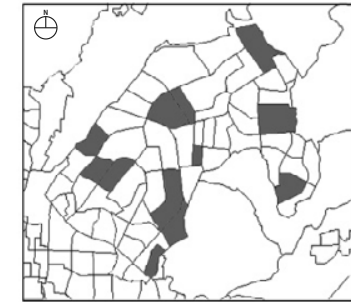

図 15 アンケート対象地区
配布日 2011 年 11 月 $19 \cdot 20$ 日

配布数 1000 戸

回収締切 2011 年 11 月 30 日

回収方法 郵送回収

回収率 31.8\%

質問項目 住居選定理由、NTに欲 しい施設

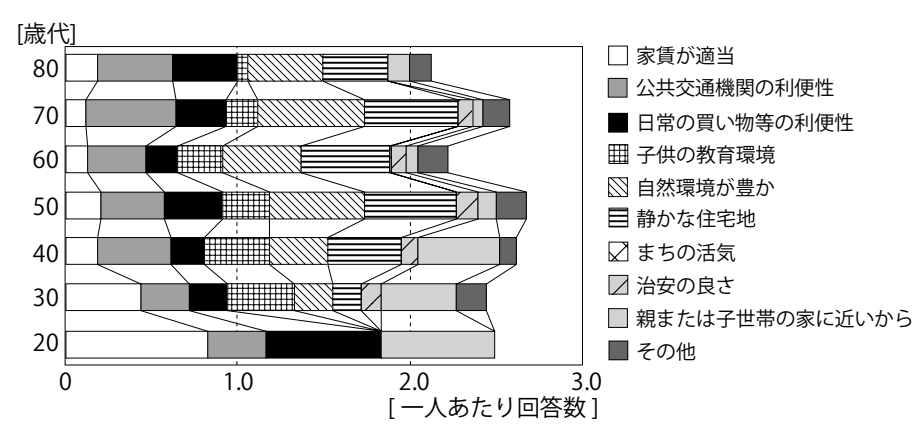

図 16 年齢別住居選定理由

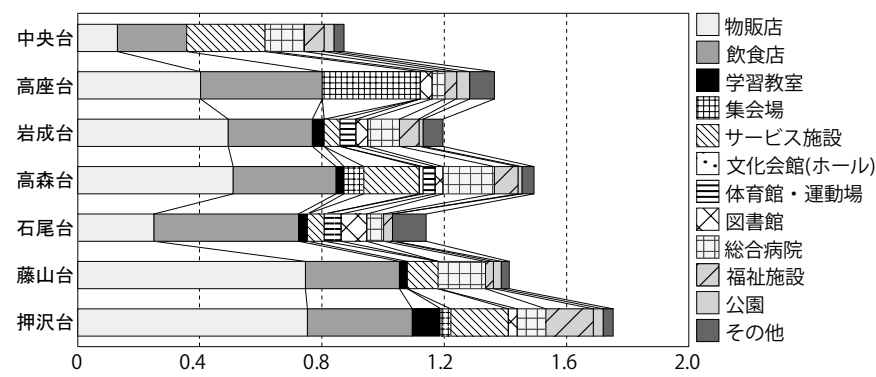

図 17 地区別施設ニーズ (自宅周辺)

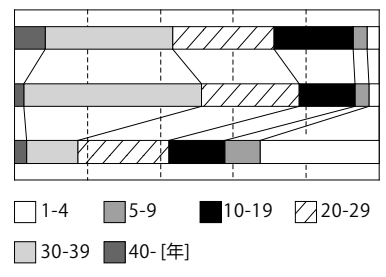

図 18 (左) 分類別居住年数 （右）分類別住居選定理由

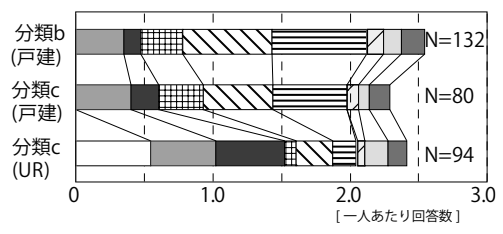

$\square$ 家賃が適当 $\square$ 公共交通機関の利便性

日常の買い物等の利便性 四子供の教育環境

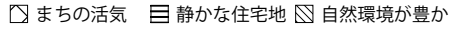
】治安の良さ $\square$ 親または子世帯の家に近い $\square$ その他
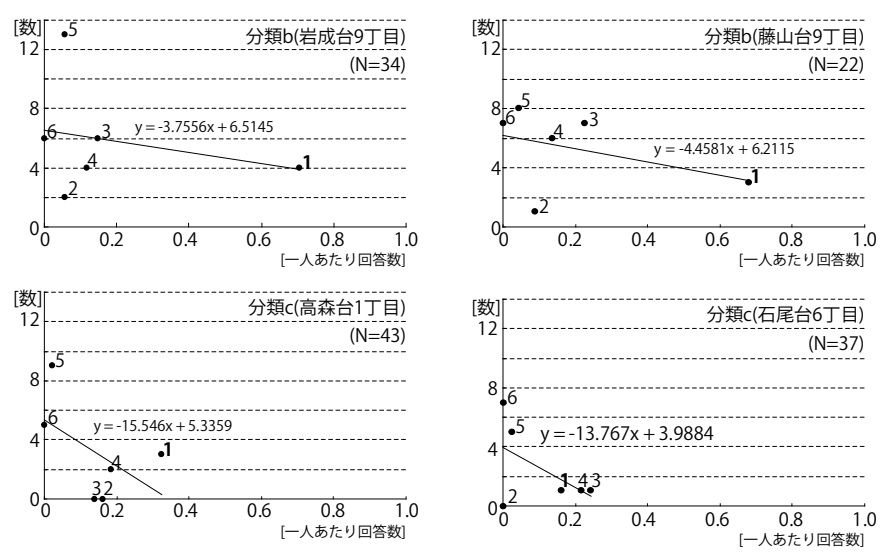

1 食料品店 2 日用雑貨・文具店 3 飲食店 4 喫茶店 5 学習教室 6 集会所 図 19 施設数と徒歩圏における施設ニーズ 


\section{6. 総括}

a）まとめ

まず、名古屋都市圈を対象として高蔵寺 NT の住宅と住民特性をみ ていくと、自宅就業者率が低く、依然として住宅単一機能都市とし ての状況を呈していた。また、UR 賃貸と持ち家世帯が混在する状況 で、様々なタイプの住宅ストックが存在しており、多世代・多様な 世帯に対応できる可能性が高いことが分かった。次に、NT 内とその 周辺で人口・世帯と住宅ストックを比較した結果、世帯循環の差が 広がっており、NT 周辺へと居住地を選定する人が増えている傾向に あることが分かった。施設分布に関しては、NT 内では施設種によっ て立地にばらつきがあり、NT 周辺では、住宅地内にも多数施設の立 地がみられ、用途の混在した市街地を形成していた。さらに、NT 内 の地区毎にみていくと世帯の循環状況に違いが見られた。また、用 途地域上施設の立地しや寸い地区では空室や空き家が増加しており、 施設の立地しにくい地区において世帯の流入が起こっていた。特に、 センターから遠いUR 賃貸地区の空室率が増大寸る一方、戸建地区で は世帯の流入があるが、飲食や物販といった自宅周辺に欲しい施設 のニーズが高い傾向にあった。

\section{b) 考察}

未だ住宅単一機能の都市となっている NT 内と比較して用途の混在 した NT 周辺へと居住地を選定する人が増えている。その理由として、 NT 周辺のほうが施設の立地が可能な地域に多くの施設が分布してい ることから買い物等利便性が高い住環境となっていることが考えら れる。すなわち、NT 内に新たな住民を迎え入れるためには、地区や 住棟レベルで用途の混在を許容することで地区としての付加価值を 与え、地区の魅力を向上させることが重要ではないかと考える。そ こで、戸建とUR 賃貸の両地区に分けて住宅ストックと施設分布の関 係を分析することで再生のための考察を述べる。

・センターから遠い戸建地区では、未だ多くの空地が存在すること から新規世帯が流入しており、今後も空き地が活用されていけば世 帯循環は継続されると考えられる。しかし、センターから遠くなる ほど飲食や物販といった自宅周辺に欲しい施設のニーズが高い傾向 にある。さらに、NT 内でそういった施設が減少して行く傾向にある ことから、用途地区による規制を一部の地区で緩和することで施設 立地を促進する等の対策が必要である。

・世帯増加率が低いUR 賃貸地区の中でセンターから遠い地区では、 空室率の増加も著しいことから衰退が急激に進行して行くことが予 想される。それは、比較的に施設の立地しやすい中高層住居専用地 域に属しているにもかかわらず、URの規定により住棟内での施設立 地を厳しく制限していることが一因として考えられる。そこで、UR 賃貸地区に住む人たちが日常の買い物等の利便性を重視することか らも住棟レベルでの用途混在を許容する等の対策が必要である。

\section{c) 今後の課題}

本研究において、施設分布の要因を主に用途地域等の規制を中心 に分析しているが、駐車場の確保といった敷地規模との関係等他の 要因も考えられる。さらに、今後新しく流入してくる住民、特に若 者層に対しての施設に関するニーズの抽出も継続的に行っていくこ とで将来的なニーズの変化も見て行く必要がある。また、文化教室 のような立地が制限される中でも活動し、根付いている施設は、NT 内のコミュニティ醸成のきっかけとなっているのではないかと考え
られ、今後地区毎に詳しく調査する必要がある。

注

注 1）名古屋市と名古屋市への 15 歳以上の通勤・通学者の割合が当該市区町村 の常住人口の $1.5 \%$ 以上であり、かつ名古屋市と連接している市区町村。た だし、名古屋市への 15 歳以上通勤・通学者数の割合が $1.5 \%$ 未満の市町村で あっても、その周囲が上記の基準に適合した市町村によって囲まれている場 合は含む。

総務省 統計局・政策統括官・統計研修所

http://www. stat. go. jp/data/kokusei/2005/users/kubun. htm\#pos4

注 2）株式会社ジェー・ピー・エス「平成 17 年国勢調査地域メッシュ全指標」

注 3) 国土交通省住宅局 計画開発住宅市街地の現状と課題

http://www. mlit. go. jp/jutakukentiku/siryou1-02.pdf

注 4）春日井市統計書平成 17 年度版、春日井市統計書平成 23 年版（住民台帳 ベース)

注 5）高蔵寺ニュータウンは春日井市の北東の縁に位置しており、東側境界に は山があり、南側境界には庄内川が南西に向かって流れている。そのため、 隣接する市とは地形的に分断されていることから春日井市外の隣接市町村は 周辺に含まなかった。一方、北西部に南西から北東に向かって延びている国 道 19 号と南西に向かって走る JR 中央線沿線に延びる市街地を含むことで ニュータウン周辺へのスプロール現象が調査できると考えそれらの町丁目が 包含できる $6 \mathrm{~km}$ 四方を周辺と定義することにした。

注 6) 下記高蔵寺ニュータウンの住戸種別と戸数は、2011 年 3 月の UR 都市機構 中部支社の独自調査による（表 4）。

表 4 NT 内の各住居種別戸数

\begin{tabular}{|c|c|}
\hline 住居種別 & 戸数 \\
\hline 戸建住宅 & 9,227 戸 $(42 \%)$ \\
\hline UR 賃貸集合住宅 & 7,961 戸 (36\%) \\
\hline UR 分譲集合住宅 & 2,427 戸 (11\%) \\
\hline 県営集合住宅 & 470 戸 $(2 \%)$ \\
\hline 社宅 & 446 戸 $(2 \%)$ \\
\hline 県公社·民間分譲住宅 & $1,307 \bar{F}(6 \%)$ \\
\hline 総住戸数 & 21,838 戸 \\
\hline
\end{tabular}

注 7) 本調查は、2005 年度国土技術政策総合研究所（受託：財団法人国土技術 研究センター)により「全国 6 地域」を対象に実施された「空き地・空き家 実態把握調査」実施要領に準じて行った（片山直紀, 海道清信, 村上心, 前田幸栄 : 空き地 ・空き家実態からみた郊外住宅団地の持続可能性につい ての考察 一名古屋都市圈・可児市と多治見市における事例調査より一, 都 市住宅学 55 号，pp. 70-75，2006. AUTUMN 参照)。高蔵寺ニュータウンは「全 国 6 地域」の拡大エリアとして、独自に追加した地域である。

空き家の目視による判断基準は、次の通りである。

a）長期間放置されている空き家 : 建築の主要部分に腐朽破損などがある（ガ ラスが割れている、雑草が繁茂している）人が期間居住している形跡がない （と思われる）住宅。

b) 季節利用（ふだん居住者がいない空家・別荘利用）：長期間放置されて腐 朽破損が進んだ住宅ではないが、二次的住宅としてときどきしか使用されて いない（と思われる）住宅。

c）分譲中・賃貸募集中の空き家 : 売却もしくは賃貸用として不動産業者など が管理している土地。「分譲中」などの看板から判断する。国有財産、民有 地の区別を明確にする。住宅建築のため整理された状態も含む。

d）上記 a） c) 以外の空き家

UR 賃貸住戸の空室調査は、「入居者の手引き」「団地の概要」などにより あらかじめ、立地や室数の確認を行なっておく。準備した住宅地図をべース に住宅地図上の集合住宅と実際の集合住宅とを照合させながら、住宅地図と 調査時点との間で区画割りなどに変化が生じていないかどうかの確認を行な いながら、調査を実施した。区画に変化（例：集合住宅が取り壊されている など）があれば、適宜地図を実態に即して修正し、集合住宅の空室における 有無の確認を各住棟において、「郵便受け」と「バルコニー」の両面から目 視により行なった。

注 8）中央台 1 丁目は戸建住宅・UR 賃貸集合住宅がほとんどないため、除いて いる。

注 9）典型例は、各分類の特徵が大きく表れている集団から選択している。分 類 a において、藤山台、岩成台等開発時期の早い町丁目に多いことから岩成 台 7 丁目を、分類 $\mathrm{b}$ において、中央センターから離れた町丁目に多いことか 
ら高森台 $6 丁$ 丁目を、そして分類 $\mathrm{c}$ において、中央センター付近の町丁目に多 いことから高森台 1 丁目を選択した。

注 10) 2011 年 12 月の空き地・空き家と 2013 年 1 月の空室の調査方法は、2005 年に行なった悉皆調査と同様とした。

注 11）岩成台 7 丁目と高森台 $6 丁$ 丁目の「空き地の増減数」と（「新規空き地一 「空き地 新築」）数に違いがあるのは、一つだった空き地が分筆され複 数の住宅が新築されたためである。

注 12) 株式会社ゼンリン「電子住宅地図デジタウン 春日井市」 2011.11

注 13) URL : http://maps. google. co. jp/

注 14）春日井市 HP で公表されているデータに基づく。

URL : http://www2. wagamachi-guide. com/kasugai/

注 15）本論文では、図中で太線により示している現在の国道・県道、また高 蔵寺ニュータウンマスタープランにおける主幹線道路と住宅幹線道路を幹 線道路と定義した。

注 16）建築基準法上、飲食店は、工業専用地域では立地ができない。第 1 種・ 第 2 種低層住居専用地域では、兼用住宅で、非住宅部分の床面積が、 $50 \mathrm{~m}^{2}$ 以下かつ建築物の延べ面積の $1 / 2$ 未満といった規模・形態等によって立地 が制限される。一方、第 1 種中高層住居専用地域の飲食店では、延べ床面 積の合計 $500 \mathrm{~m}^{2}$ 以下でかつ 2 階以下の建築制限を受けるが、NT 内外の店舗 規模を見て、今回はこれらの地域を立地が可能な地域に分類している。ま た、第 1 種中高層住居専用地域よりも立地制限が緩和される第 2 種中高層 住居専用地域、第 1 種住居地域、第 2 種住居地域、準住居地域、工業地域 においても立地が可能な地域であるとしている。参考のため、表 5 に 15 の 対象業種の用途地域毎の建築制限を示す。

\section{表 5 対象業種の用途地域による制限}

\begin{tabular}{|c|c|c|c|c|c|c|c|c|c|c|c|c|}
\hline & 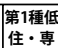 & $\begin{array}{l}\text { 第2種低接 } \\
\end{array}$ & \begin{tabular}{|l} 
第1種中 \\
住 - 専
\end{tabular} & \begin{tabular}{|l|} 
第2種中 \\
住
\end{tabular} & 第1種任 & 第2 種住 & 準住居 & $\begin{array}{l}\text { 近隣 } \\
\text { 商業 }\end{array}$ & 商業 & 準工業 & 工業 & $\begin{array}{l}\text { 工業 } \\
\text { 專用 }\end{array}$ \\
\hline 商店・スーパー & $\Delta$ & $\Delta$ & 0 & 0 & 0 & 0 & 0 & 0 & 0 & 0 & 0 & $x$ \\
\hline 茶店 & $\Delta$ & $\Delta$ & 0 & 0 & 0 & 0 & 0 & 0 & 0 & 0 & 0 & $x$ \\
\hline 飧店 & $\bar{\Delta}$ & $\bar{\Delta}$ & 0 & 0 & 0 & 0 & 0 & 0 & 0 & 0 & 0 & $x$ \\
\hline & $\Delta$ & $\vec{\Delta}$ & 0 & 0 & 0 & 0 & 0 & 0 & 0 & 0 & 0 & $\widehat{\Delta}$ \\
\hline 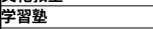 & & $\Delta$ & $\Delta$ & $\Delta$ & $\Delta$ & $\Delta$ & $\Delta$ & 0 & 0 & 0 & $\Delta$ & $\Delta$ \\
\hline 容院・理容院 & $\Delta$ & $\Delta$ & 0 & O & 0 & O & O & 0 & 0 & 0 & O & $\Delta$ \\
\hline 食料品店 & $\Delta$ & $\Delta$ & 0 & 0 & 0 & 0 & 0 & 0 & 0 & 0 & 0 & $x$ \\
\hline 院・歯科 & & $\Delta$ & 0 & 0 & 0 & 0 & 0 & 0 & 0 & 0 & $\Delta$ & $\Delta$ \\
\hline & & $\Delta$ & 0 & 0 & 0 & 0 & 0 & 0 & 0 & 0 & 0 & $x$ \\
\hline • 履 & $\Delta$ & $\Delta$ & 0 & 0 & 0 & 0 & 0 & 0 & 0 & 0 & 0 & $x$ \\
\hline 百用雑 & $\Delta$ & $\Delta$ & 0 & 0 & 0 & 0 & 0 & 0 & 0 & 0 & 0 & $x$ \\
\hline 辑店 & $\Delta$ & $\Delta$ & 0 & 0 & 0 & 0 & 0 & 0 & 0 & 0 & 0 & $x$ \\
\hline 各種事務所 & $\Delta$ & $\Delta$ & 0 & 0 & 0 & 0 & 0 & 0 & 0 & 0 & 0 & $\ddot{\Delta}$ \\
\hline 曰ンビニエン & $\vec{x}$ & $\Delta$ & 0 & 0 & 0 & 0 & 0 & 0 & 0 & 0 & 0 & $\frac{\Delta}{x}$ \\
\hline スナック・居酒屋 & $\hat{\Delta}$ & $\Delta$ & 0 & 0 & 0 & 0 & 0 & 0 & 0 & 0 & 0 & $\hat{x}$ \\
\hline
\end{tabular}

注 17) 調査方法は、対象地区内の住宅の郵便受けに直接アンケート調査票を 投函し、家族の誰か一人に回答を依頼、郵送にて回収した。配布日は 2011 年 11 月 $19 \cdot 20$ 日、回収締切は 2011 年 11 月 30 日。

アンケート調査方法の詳細を以下に示す。

NT 内の 7 の全ての町を調査対象地とし、各町の総世帯数が 3000 世帯未満の 場合 100 部、3000 世帯以上の場合 200 部の合計 1000 部のアンケートを配布 した。さらに、各町の戸建とUR 賃貸集合住宅の世帯数の比を考慮して配布 することで偏りのない回答が得られるよう決定した（表 6)。選定した戸建 住宅は、空き家を除いた番地数の小さい順とし、UR 賃貸住戸は、空室を除 いた住棟番号と部屋番号の小さい順に配布した。

表 6 調查対象地区と回収率

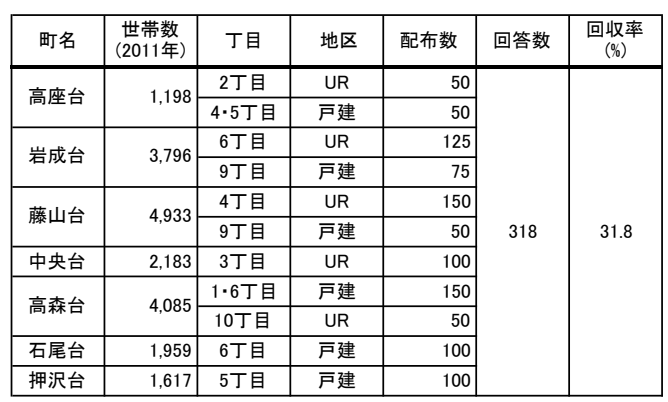

注 18）松橋が「公共交通機関の停留所立地が徒歩圏人口に与える影響」（松 橋啓介 : 2002 年度第 37 回日本都市計画学会学術研究論文集, pp. 157-162) の中で「容易に歩行できる距離を $250 \mathrm{~m}$ (2 4 分), 歩行可能な距離を $500 \mathrm{~m}$ (5 8 分)」としていること、そして、石原が平成 18 年度名古屋都市 センター研究報告書「日常生活圏域の基礎的研究」

(http://www. nui. or. jp/kenkyu/18kenkyupdf/h18a. pdf) の中で徒歩圈を
$500 \mathrm{~m}$ 以内と定義していることを参考にして、本論において徒歩圈距離を $500 \mathrm{~m}$ とした。

\section{参考文献}

1 ）原田陽子：高蔵寺ニュータウンにおける住宅ストック、居住世帯と住み替 えとの可能性 - 郊外大規模団地の再生に関寸る研究-, 日本建築会計画系論 文集，№. 618 , pp. 9-16，2007.8

2 ）片山直紀，海道清信，村上心，前田幸栄：空き地・空き家実態からみた 郊外住宅団地の持続可能性についての考察 - 名古屋都市圈・可児市と多治見 市における事例調査より -, 都市住宅学，No. 55，pp. 70-75，2006. 10

3 ）小西沙恵, 西岡絵美子, 横田隆司 : 戸建て住宅団地の空き家と空き地の 現状に関する研究 -千里ニュータウンを対象に-, 日本建築学会近畿支部研 究報告集, No. 48, pp. 25-28, 2008. 5

4 ) 菊池吉信, 玉置伸俉 : 世帯移動に伴う空き家数の変化に関する検討中古借 家市場の有効性に関寸る研究 (その 1), 日本建築学会計画系論文集, No. 533, pp. 151-156, 2000.7

5 ) 森田孝夫 : 高蔵寺ニュータウンにおける地域施設の自然発生実態に関する 調査報告」, 日本建築学会計画系論文報告集, No. 453, pp. 61-70, 1993.11

6 ）柏原士郎, 岡田光正, 吉村英祐, 横田隆司・金漢洙 : 開発手法と地域施 設分布パターンおよび発生量の関係について，日本建築学会計画系論文集， No. 404, pp. $69-78,1989.10$

7 ) 石橋登, 谷口汎邦 : 多摩田園都市における生活関連施設の立地経緯につい て, 土地区画整理事業の組み合わせによって作られた郊外住宅地計画に関す る研究 その 3, 日本建築学会計画系論文集, No. 635, pp. 41-50, 2009. 1

8 ）伊藤義浩 : 都市の縮退からみるニュータウンの分類・分析・東海三県の計 画開発住宅市街地について -, 名古屋大学卒業論文 2010.2 から引用。

9 ）金漢洙，岡田光正，柏原士郎，吉村英祐，横田隆司：土地区画整理によ り開発されたニュータウンにおける地域施設発生の予測方法について, 日本 建築学会計画系論文集 No. 407, pp. 97-105, 1990.1

（2013年 6 月10日原稿受理，2013年11月25日採用決定） 